\title{
ANALISIS STRUKTUR KOMUNITAS MAKROZOOBENTHOS SEBAGAI BIOINDIKATOR KUALITAS PERAIRAN SUNGAI WEDUNG KABUPATEN DEMAK
}

\author{
Aqil Mushthofa, Max Rudolf Muskananfola, Siti Rudiyanti ${ }^{1}$
}

Program Studi Manajemen Sumberdaya Perairan, Jurusan Perikanan

Fakultas Perikanan dan Ilmu Kelautan, Universitas Diponegoro

\begin{abstract}
ABSTRAK
Potensi sumberdaya perikanan di perairan Sungai Wedung Kabupaten Demak sangat dipengaruhi oleh kondisi perairan yang berasal dari sungai yang semakin hari semakin tercemar. Banyaknya bahan pencemar dalam perairan dapat mempengaruhi organisme perairan, bahkan dapat membunuh spesies tertentu. Makrozoobenthos dalam perairan memiliki peranan yang sangat penting yaitu sebagai organisme yang berperan sebagai indikator biologi suatu perairan. Bahan organik yang terkandung dalam substrat dasar erat kaitannya dengan makrozoobenthos, karena bahan organik merupakan sumber nutrien bagi organisme air. Tujuan penelitian ini adalah untuk mengetahui komposisi dan kelimpahan makrozoobenthos, mengetahui hubungan bahan organik dengan kelimpahan makrozoobenthos serta menilai kondisi atau tingkat pencemaran perairan di sungai. Penelitian dilaksanakan pada bulan April-Mei 2013 di perairan Sungai Wedung Kabupaten Demak. Checklist makrozoobenthos dan analisis sedimen dilakukan di Laboratorium Manajemen Sumberdaya Perairan, Jurusan Perikanan, Fakultas Perikanan dan Ilmu Kelautan Universitas Diponegoro. Makrozoobenthos yang didapatkan selama penelitian di Sungai Wedung terdiri dari 3 kelas yaitu Polychaeta, Gastropoda, dan Bivalve. Kelimpahan terbesar terdapat pada stasiun C, sedangkan kelimpahan terendah pada stasiun A. Nilai indeks keanekaragaman stasiun A sebesar 1,230; stasiun B sebesar 0,340; dan stasiun C sebesar 0,295. Hasil analisis regresi antara kandungan bahan organik dengan kelimpahan makrozoobenthos didapatkan nilai koefisien korelasi (r) sebesar 0,839 artinya bahwa terdapat hubungan yang erat antara kandungan bahan organik dengan kelimpahan makrozoobenthos. Semakin tinggi bahan organik, maka semakin tinggi juga kelimpahan makrozoobenthos. Kandungan bahan organik di ketiga stasiun termasuk dalam kategori tinggi. Tingginya bahan organik ini berasal dari peningkatan aktivitas manusia seperti kegiatan pertanian, pemukiman, serta keberadaan limbah buangan TPI Wedung. Kondisi perairan di stasiun A tercemar sedang, sedangkan pada stasiun B dan stasiun $\mathrm{C}$ tercemar berat.
\end{abstract}

Kata Kunci: Makrozoobenthos, Struktur Komunitas, Bioindikator, Tingkat Pencemaran, Bahan Organik, Sungai Wedung.

\begin{abstract}
Potential fishery resources in the waters of the Wedung River in Demak Regency is strongly influenced by the condition of the water that comes from rivers that are increasingly polluted. Amount of pollutants in the water can affect to aquatic organisms, may even kill certain species. Macrozoobenthos in the water has important role is biological indicator of the waters. Organic materials contained in the bottom substrate is closely related to macrozoobenthos, because organic matter is a source of nutrients for aquatic organisms. The purpose of this research was to know the composition and density of macrozoobenthos and assess the condition or level of water pollution in the river. The research was conducted in April to May 2013 in the waters of the Wedung River in Demak Regency. Checklist of macrozoobenthos and analysis of sediment were carried out in the Laboratory of Management Resource Aquatic of Department of Fisheries, Faculty of Fisheries and Marine Science, Diponegoro University. Macrozoobenthos were obtained during the research in the Wedung River consist of 3 classes that is Polychaeta, Gastropod, and Bivalves. The greatest abundance found at station $\mathrm{C}$, while the lowest abundance at station A. Value of diversity index in station A is 1.230 ; in station B is 0.340 , and 0.295 for station C. Results of regression analysis between organic matter with an abundance of macrozoobenthos obtained correlation coefficient (r) is 0.839 , this means that there is a close relasionship between total organic matter with abundance of macrozoobenthos. The higher the organic matter, the higher also the abundance of macrozoobenthos. Total organic matter in the three stations in the high category. The high organic matter is derived from increasing human activities such as agricultural, residential, and the presence of waste from TPI Wedung. Water conditions of station A is moderately polluted, while at station $\mathrm{B}$ and station $\mathrm{C}$ are heavily polluted.
\end{abstract}

Keywords: Macrozoobenthos, Community Structure, Bioindicators, Pollution Levels, Organic Matter, Wedung River. 


\section{Pendahuluan}

Sungai merupakan suatu bentuk ekosistem akuatik yang mempunyai peran penting dalam daur hidrologi dan berfungsi sebagai daerah tangkapan air (Catchment area) bagi daerah sekitarnya, sehingga kondisi suatu sungai sangat dipengaruhi oleh karakteristik yang dimiliki oleh lingkungan sekitarnya. Sebagai suatu ekosistem, perairan sungai mempunyai berbagai komponen biotik dan abiotik yang saling berinteraksi membentuk suatu jalinan fungsional yang saling mempengaruhi (Setiawan, 2009). Potensi sumberdaya perikanan di perairan Sungai Wedung di Kecamatan Wedung, Demak sangat dipengaruhi oleh kondisi perairan tersebut, terutama perairan yang berasal dari sungai yang semakin hari semakin tercemar. Banyaknya bahan pencemar dalam perairan dapat memberikan pengaruh terhadap organisme perairan, bahkan dapat membunuh spesies tertentu dan sebaliknya dapat mendukung perkembangan spesies lain.

Organisme yang hidup di perairan seperti makrozoobenthos sangat peka terhadap perubahan kualitas air tempat hidupnya sehingga akan berpengaruh terhadap komposisi dan kelimpahannya. Hal ini tergantung pada toleransinya terhadap perubahan lingkungan, sehingga organisme ini sering dipakai sebagai indikator tingkat pencemaran suatu perairan. Selain itu, makrozoobenthos merupakan organisme akuatik yang hidup di dasar perairan dengan pergerakan relatif lambat dan menetap serta daur hidupnya relatif lama sehingga hewan tersebut mempunyai kemampuan merespon kondisi kualitas air secara terus menerus (Mason, 1993 dalam Setiawan, 2010). Salah satu faktor yang menjadikan makrozoobenthos sebagai bioindikator untuk kualitas perairan dilihat berdasarkan sifatnya yaitu bersifat ubiquitous yaitu sebarannya luas, jumlah spesies lebih banyak dapat memberikan spektrum respon terhadap tekanan lingkungan. Selain itu cara hidup makrozoobenthos yang relatif menetap (sedentary) pada habitatnya dan juga memiliki siklus hidup lebih panjang memungkinkan menjelaskan perubahan temporal. (Rosenberg and Resh, 1993). Permasalahan yang terjadi di sekitar Sungai Wedung Kecamatan Wedung, Demak diantaranya penggunaan sungai sebagai tempat pembuangan limbah domestik yang berasal dari pemukiman maupun limbah non-domestik yang berasal dari kegiatan pertanian, tambak, serta kegiatan di TPI Wedung yang membuang limbahnya langsung ke badan sungai. Aktivitas masyarakat yang berada di daerah aliran sungai secara langsung maupun tidak langsung akan memberikan dampak negatif terhadap kualitas air sungai seperti faktor fisika, kimia, maupun biologi yang selanjutnya dapat mengakibatkan rusaknya ekosistem perairan. Rusaknya ekosistem perairan tersebut akan berdampak juga terhadap kehidupan biota air seperti perubahan struktur komunitas makrozoobenthos, dimana penurunan kelimpahan dan komposisi dari organisme tersebut biasanya merupakan indikator adanya gangguan ekologi yang terjadi pada suatu perairan sungai. Bahan organik yang terdapat pada substrat dasar perairan Sungai Wedung berasal dari berbagai aktivitas yang ada di sekitar daerah aliran sungai. Kandungan bahan organik mempunyai hubungan yang sangat erat terhadap kelimpahan makrozoobenthos yaitu sebagai sumber nutrien. Hal ini menunjukkan bahwa ketersediaan bahan organik pada substrat dasar berpengaruh terhadap kelimpahan makrozoobenthos.

Tujuan dari penelitian ini adalah untuk mengetahui komposisi dan kelimpahan makrozoobenthos, mengetahui hubungan antara kandungan bahan organik dengan kelimpahan makrozoobenthos serta mengetahui kondisi atau tingkat pencemaran perairan dengan menggunakan makrozoobenthos sebagai bioindikator kualitas perairan sungai. Hasil dari kegiatan penelitian ini diharapkan dapat memberikan informasi mengenai struktur komunitas makrozoobenthos sebagai bioindikator kualitas perairan sungai. Selanjutnya informasi ini dapat digunakan sebagai salah satu pertimbangan dalam upaya pengelolaan wilayah perairan Sungai Wedung.

\section{Materi dan Metode Penelitian}

\section{A. Materi Penelitian}

Materi yang dikaji dalam penelitian ini adalah struktur komunitas makrozoobenthos di perairan Sungai Wedung Kecamatan Wedung, Demak. Alat yang digunakan dalam penelitian ini yaitu Eikman Grab digunakan mengambil sampel substrat. Kantong plastik dan botol sampel digunakan untuk wadah sampel substrat dan makrozoobenthos. Saringan untuk memisahkan makrozoobenthos dengan kotoran. Ember untuk mengambil sampel air. Termometer air raksa untuk mengukur suhu air, $\mathrm{pH}$ paper untuk mengukur $\mathrm{pH}$, DO meter untuk mengukur oksigen terlarut, current meter untuk mengukur kecepatan arus, secchi disc untuk mengukur kecerahan, mikroskop binokuler untuk mengamati makrozoobenthos. Alat yang digunakan untuk analisis tekstur tanah diantaranya penumbuk porselen, oven, timbangan analitik, sieve shaker, alumunium foil, gelas ukur dan gelas beker, serta pipet ukur. Bahan yang digunakan dalam penelitian ini yaitu makrozoobenthos dan sedimen yang berasal dari Sungai Wedung. Larutan rose bengal untuk pewarnaan makrozoobenthos serta formalin $4 \%$ untuk mengawetkan sampel makrozoobenthos.

\section{B. Metode Penelitian}

Metode yang digunakan dalam penelitian ini adalah metode deskriptif. Menurut Nazir (1999), metode deskriptif bertujuan untuk menggambarkan atau melukiskan secara sistematis, faktual dan akurat mengenai fakta-fakta, sifat-sifat, hubungan antar fenomena atau peristiwa yang sedang diselidiki. Percobaan yang dilakukan dalam penelitian ini adalah dengan mengumpulkan data yang terdiri dari data faktor fisika, kimia dan biologi yang berasal dari lapangan. Data yang didapatkan selanjutnya dilakukan pengolahan dan analisis. 


\section{Prosedur penelitian}

Prosedur penelitian terdiri dari penetapan lokasi sampling, pengambilan sampel, dan checklist makrozoobenthos. Penetapan lokasi sampling diawali dengan melakukan survei pendahuluan untuk menentukan stasiun pengambilan sampel dan titik sampling penelitian. Stasiun pengambilan sampel yaitu pada perairan sungai sekitar persawahan (Stasiun A), perairan sungai sekitar pemukiman (Stasiun B) dan perairan sungai sekitar pertambakkan (Stasiun C). Pengambilan sampel berupa sedimen dam makrozoobenthos menggunakan Eikman Grab sebanyak 3 kali yaitu pada bagian tepi kanan sungai, bagian tengah, dan bagian tepi kiri sungai pada 3 stasiun yang berbeda dengan interval waktu pengambilan sampel 2 minggu sekali. Deskripsi pengambilan sampel dijelaskan pada gambar 1. Proses Checklist makrozoobenthos dilakukan dengan cara mengamati ciri-ciri morfologi menggunakan mikroskop binokuler dengan mengacu pada buku petunjuk checklist makrozoobenthos.

\begin{tabular}{|c|c|c|c|c|c|c|c|c|}
\hline & & & & iplir & & & & \\
\hline & asiun & & & ssiur & & & Isiun & \\
\hline A1 & A2 & A3 & B1 & B2 & B3 & $\mathrm{C} 1$ & $\mathrm{C} 2$ & C3 \\
\hline & & & & npli & & & & \\
\hline & asiun & & & asiu & & & asiur & \\
\hline A1 & A2 & A3 & B1 & B2 & B3 & $\mathrm{C} 1$ & C2 & C3 \\
\hline & & & & npli & & & & \\
\hline & asiun & & & asiu & & & asiu & \\
\hline A1 & A2 & A3 & B1 & B2 & B3 & $\mathrm{C} 1$ & $\mathrm{C} 2$ & C3 \\
\hline
\end{tabular}

Gambar 1. Titik Sampling, Stasiun Pengambilan Sampel, dan Interval Waktu Sampling

\section{Pengumpulan data}

Pengumpulan data dengan cara melakukan analisis struktur komunitas makrozoobenthos, analisis tektur tanah dan kandungan bahan organik serta analisis regresi antara kandungan bahan organik dengan kelimpahan makrozoobenthos. Data pendukung didapatkan dari hasil pengukuran parameter kualitas air yang dilakukan langsung di lapangan, meliputi suhu air, kecerahan, kedalaman, kecepatan arus, derajat keasaman $(\mathrm{pH})$, oksigen terlarut (DO), dan salinitas.

\section{Analisa data}

Analisis data menggunakan analisis statistik deskriptif. Statistik deskriptif adalah statistik yang digunakan untuk menganalisis data dengan cara mendeskripsikan atau menggambarkan data yang telah terkumpul (Setyowati dkk., 2010).

Statistika deskriptif merupakan bagian statistika yang membicarakan cara-cara pengumpulan data dan menyederhanakan angka-angka atau ingin mengetahui gambaran data yang kita peroleh dari hasil pendataan di lapangan atau di laboratorium dengan cara menyajikan data ke dalam tabel, grafik, menemukan nilai pemusatan dan nilai penyebaran (Ismiyati dkk., 2004).

Berdasarkan hasil penelitian, hubungan antara kandungan bahan organik dengan kelimpahan makrozoobenthos dianalisis menggunakan analisis regresi linier yang diolah menggunakan software SPSS 16 untuk melihat adanya hubungan antara kandungan bahan organik dengan kelimpahan makrozoobenthos.

\section{Analisis Tekstur Tanah}

Penentuan fraksi tanah menggunakan metode pemipetan yang mengacu pada analisis tekstur tanah menurut Buchanan (1971) dengan prosedur kerja sebagai berikut :

1. Mengambil sampel 25 gram, dimasukkan dalam saringan dengan mesh size $0,063 \mathrm{~mm}$ dan diayak dalam baskom yang berisi 1 liter air, sehingga terjadi dua bagian yaitu sampel yang lolos saringan dan yang mengendap, serta sampel yang tidak lolos.

2. Sampel yang tidak lolos saringan, diambil dan dikeringkan dalam oven dengan suhu $100^{\circ} \mathrm{C}$.

3. Setelah sampel kering, disaring dengan saringan bertingkat. Sampel yang tersaring pada masing-masing tingkat diletakkan di atas kertas saring dan ditimbang. (tingkat $\mathrm{I}=\mathrm{a}$ gram, tingkat $\mathrm{II}=\mathrm{b}$ gram dan seterusnya sampai sampel yang terletak paling bawah yang tidak tersaring). 


\section{http://ejournal-sl.undip.ac.id/index.php/maquares}

4. Hasil saringan paling bawah dicampur dengan sampel yang lolos pada penyaringan pertama (yang tertinggal dalam baskom) dan dipindahkan dalam gelas ukur 1 liter. Selanjutnya gelas ukur dikocok dan siap dilakukan pemipetan.

5. Pemipetan pertama berjarak $20 \mathrm{~cm}$ dari atas, setelah waktu 58 detik. Selanjutnya diletakan pada gelas beker kemudian dioven, dan ditimbang misal a gram. Pemipetan kedua setelah waktu 1 menit 56 detik dan berjarak $10 \mathrm{~cm}$ dari pemipetan pertama, misalnya $\mathrm{b}$ gram. Pemipetan selanjutnya secara rinci sesuai tabel 1 di bawah ini :

Tabel 1. Waktu Tenggelam Partikel Dalam Air Suling

\begin{tabular}{ccccc}
\hline Diameter & Jarak Tenggelam & Jam & Menit & Detik \\
\hline 0,0625 & $20 \mathrm{~cm}$ & 0 & 0 & 58 \\
0,0312 & $10 \mathrm{~cm}$ & 0 & 1 & 56 \\
0,0156 & $10 \mathrm{~cm}$ & 0 & 7 & 44 \\
0,0078 & $10 \mathrm{~cm}$ & 0 & 31 & 0 \\
0,0039 & $10 \mathrm{~cm}$ & 2 & 3 & 0 \\
\hline
\end{tabular}

6. Hasil pemipetan dikonversikan ke dalam volume 1 liter (volume pipet yang digunakan adalah $20 \mathrm{ml}$ ) sehingga didapatkan untuk pemipetan pertama a dan pemipetan kedua $b$.

Analisis Kandungan Bahan Organik

Analisis kadar bahan organik menggunakan metode Gravimetri. Dalam metode ini semua bahan organik dianggap volatile (menguap) bila dibakar pada suhu $550^{\circ} \mathrm{C}$ selama 4 jam.

1. Sampel sedimen diambil sekitar 20 gram, kemudian dikeringkan dalam oven suhu $60^{\circ} \mathrm{C}$ selama $24 \mathrm{jam}$ hingga kering dan dapat digerus.

2. Sampel sedimen yang telah kering digerus dengan penumbuk porselen hingga halus kemudian dimasukkan ke dalam oven hingga kering benar (kurang lebih selama 2 jam).

3. Setelah sedimen kering mutlak, ditimbang sekitar 0,5 gram dan ditampung dalam cawan porselen volume $5 \mathrm{ml}$, kemudian dibakar dengan alat pengabuan (furnance) yang suhunya telah mencapai $550^{\circ} \mathrm{C}$ selama 4 jam.

4. Dari hasil yang diperoleh, kemudian dilakukan perhitungan, dimana berat sampel yang hilang selama proses pembakaran merupakan jumlah bahan organik yang terkandung dalam material sedimen. Perhitungan kadar bahan organik menggunakan rumus:

$$
\% \mathrm{BO}=\frac{W 0-W t}{w 0} \times 100 \%
$$

Keterangan :

$\% \mathrm{BO}=$ Persentase bahan organik sedimen

$\mathrm{W} 0=$ Berat material sedimen awal

$\mathrm{Wt}=$ Berat material sedimen yang tersisa setelah pemanasan $550^{\circ} \mathrm{C}$

\section{Hasil dan Pembahasan}

\section{Komposisi dan Kelimpahan Makrozoobenthos}

Makrozoobenthos yang didapatkan selama penelitian di Sungai Wedung Kecamatan Wedung terdiri dari 3 kelas yaitu Polychaeta, Gastropoda, dan Bivalve. Komposisi dan kelimpahan makrozoobenthos yang diperoleh pada masing-masing stasiun tersaji pada tabel 2 berikut:

Tabel 2. Komposisi dan Kelimpahan Makrozoobenthos di Sungai Wedung Kabupaten Demak

\begin{tabular}{|c|c|c|c|c|c|c|c|c|c|}
\hline \multirow{3}{*}{ Biota } & \multicolumn{9}{|c|}{ STASIUN } \\
\hline & \multicolumn{3}{|c|}{$\mathrm{A}$} & \multicolumn{3}{|c|}{$\mathrm{B}$} & \multicolumn{3}{|c|}{$\mathrm{C}$} \\
\hline & 1 & 2 & 3 & 1 & 2 & 3 & 1 & 2 & 3 \\
\hline \multicolumn{10}{|l|}{ Polychaeta } \\
\hline Nereis sp. & 0 & 0 & 5 & 0 & 0 & 3 & 0 & 3 & 4 \\
\hline Nepthys sp. & 1 & 2 & 5 & 2 & 4 & 9 & 0 & 8 & 9 \\
\hline Sphaerodoropsis sp. & 5 & 0 & 0 & 1 & 0 & 0 & 0 & 0 & 0 \\
\hline \multicolumn{10}{|l|}{ Gastropoda } \\
\hline Melanoides sp. & 5 & 19 & 26 & 87 & 76 & 87 & 181 & 203 & 202 \\
\hline Lymnaea sp. & 0 & 0 & 0 & 0 & 0 & 0 & 1 & 1 & 0 \\
\hline Physa sp. & 0 & 0 & 0 & 0 & 0 & 0 & 0 & 1 & 0 \\
\hline \multicolumn{10}{|l|}{ Bivalve } \\
\hline Dreissena sp. & 5 & 6 & 4 & 1 & 0 & 1 & 1 & 8 & 1 \\
\hline Sphaerium sp. & 0 & 1 & 0 & 0 & 0 & 0 & 0 & 0 & 0 \\
\hline Jumlah & 16 & 28 & 40 & 91 & 80 & 100 & 183 & 224 & 216 \\
\hline Total & & 84 & & & 271 & & & 623 & \\
\hline Kelimpahan (Ind/ $\mathrm{m}^{3}$ ) & & 622 & & & 2.007 & & & 4.615 & \\
\hline
\end{tabular}

Sumber : Data Primer Penelitian di Perairan Sungai Wedung Kabupaten Demak Tahun 2013 


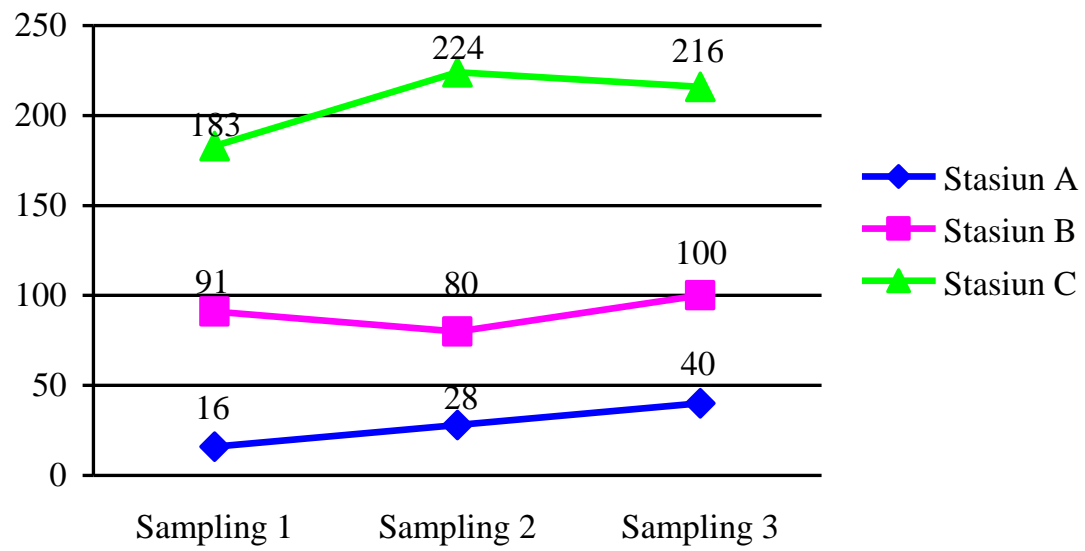

Gambar 2. Grafik Kelimpahan Makrozoobenthos di Sungai Wedung Kabupaten Demak

Gambar 2 menunjukkan kelimpahan makrozoobenthos yang didapatkan selama penelitian dengan nilai total kelimpahan 622 individu $/ \mathrm{m}^{3}$ pada stasiun A, 2.007 individu $/ \mathrm{m}^{3}$ pada stasiun B, dan 4.615 individu $/ \mathrm{m}^{3}$ pada stasiun C. Grafik menunjukkan nilai kelimpahan makrozoobenthos tertinggi adalah pada stasiun $\mathrm{C}$ dan terendah pada stasiun A. Tingginya nilai kelimpahan pada stasiun $\mathrm{C}$ diduga karena stasiun $\mathrm{C}$ merupakan perairan sungai di sekitar daerah pertambakkan dengan substrat dasar berupa liat yang memiliki kandungan bahan organik tertinggi dibandingkan dengan stasiun A dan B. Tingginya bahan organik di stasiun $\mathrm{C}$ merupakan sumber nutrien bagi biota di sekitar. Menurut Nurracmi dan Marwan (2012), menyatakan bahwa hewan benthos erat kaitannya dengan tersedianya bahan organik yang terkandung dalam substrat, karena bahan organik merupakan sumber nutrien bagi biota yang pada umumnya terdapat pada substrat dasar.

Total kelimpahan makrozoobenthos terkecil yaitu 622 individu $/ \mathrm{m}^{3}$ yang terdapat pada stasiun A dimana stasiun A memiliki substrat dasar perairan dengan komposisi farksi liat lebih tinggi dari stasiun yang lainnya, sehingga kondisi perairan di stasiun A lebih keruh dan penetrasi cahaya yang masuk ke dalam perairan lebih sedikit. Hal ini berpengaruh terhadap keberadaan makrozoobenthos yang ada di sekitarnya. Menurut Effendi (2003), kekeruhan yang tinggi dapat mengakibatkan terganggunya sistem pernafasan dan daya lihat organisme akuatik, serta dapat menghambat penetrasi cahaya yang masuk ke dalam perairan.

\section{Indeks Keanekaragaman, Indeks Keseragaman dan Indeks Dominasi}

Indeks keanekaragaman, indeks keseragaman dan indeks dominasi makrozoobenthos pada masingmasing stasiun tersaji dalam tabel 3 berikut:

Tabel 3. Indeks Keanekaragaman, Keseragaman dan Dominasi Makrozoobenthos di Sungai Wedung

\begin{tabular}{lccc}
\hline \multirow{2}{*}{ Indeks } & \multicolumn{3}{c}{ Stasiun Pengambilan Sampel } \\
\cline { 2 - 4 } & $\mathrm{A}$ & $\mathrm{B}$ & $\mathrm{C}$ \\
\hline Keanekaragaman (H') & 1,230 & 0,340 & 0,295 \\
Keseragaman (e) & 0,686 & 0,211 & 0,165 \\
Dominasi (D) & 0,354 & 0,851 & 0,891 \\
\hline
\end{tabular}

Pada Tabel 3 dapat dilihat bahwa nilai indeks keanekaragaman pada ketiga stasiun kurang dari 2,3. Nilai indeks keseragaman pada stasiun A mendekati 1, sedangkan pada stasiun B dan stasiun C mendekati 0 . Sebaliknya, nilai indeks dominasi pada stasiun A mendekati 0, sedangkan pada stasiun B dan Stasiun C mendekati 1. Indeks keanekaragaman makrozoobenthos di ketiga stasiun dalam kategori rendah. Hal ini sesuai dengan kriteria menurut Odum (1971), bahwa kriteria indeks keanekaragaman $\mathrm{H}^{\prime}<2,3$ termasuk keanekaragaman rendah.

Indeks keseragaman pada stasiun A sebesar 0,686 artinya penyebaran individu tiap jenis di stasiun A merata dan tidak ada spesies yang mendominasi. Pada stasiun B sebesar 0,211 dan pada stasiun C sebesar 0,165 artinya penyebaran individu tiap jenis di stasiun B dan stasiun $\mathrm{C}$ tidak merata dan ada biota yang mendominasi yaitu Melanoides sp. Menurut Odum (1971), jika nilai indeks keseragaman mendekati 0, maka penyebaran individu tiap jenis tidak merata, sebaliknya jika nilai indeks keseragaman mendekati 1 , maka peyebaran individu tiap jenis semakin merata dan tidak ada spesies yang mendominasi. Nilai indeks dominasi berkisar antara $0-1$, dimana semakin kecil nilai indeks dominasi maka menunjukan bahwa tidak ada spesies yang mendominasi, sebaliknya semakin besar nilai indeks dominasinya, maka menunjukan bahwa ada dominasi dari spesies tertentu (Odum, 1993).

Adanya dominasi suatu organisme menandakan bahwa tidak semua makrozoobenthos memiliki daya adaptasi dan kemampuan bertahan hidup yang sama di suatu tempat (Fitriana, 2005). Selain itu, dominasi 
Melanoides sp. di Stasiun B dan Stasiun C, ada kaitanya dengan tingginya bahan organik di kedua stasiun tersebut. Zulkifli (2009), mengemukakan bahwa kandungan bahan organik yang tinggi juga dapat berpengaruh pada kelimpahan organisme jenis tertentu yaitu yang bersifat fakultatif, dimana organisme ini tahan terhadap tingginya kandungan bahan organik sehingga jumlahnya akan melimpah, bahkan memungkinkan dominasi spesies tertentu dapat terjadi.

Hasil Analisis Tekstur Tanah dan Kandungan Bahan Organik

Hasil analisis tekstur tanah dan kandungan bahan organik tersaji pada tabel 4 sebagai berikut:

Tabel 4. Hasil analisis tektur tanah dan kandungan bahan organik sedimen di Sungai Wedung Kabupaten Demak

\begin{tabular}{ccccccc}
\hline \multirow{2}{*}{ Stasiun } & \multicolumn{3}{c}{ Tekstur Tanah } & \multicolumn{2}{c}{ Bahan Organik } \\
\cline { 2 - 6 } & Clay $(\%)$ & Slit $(\%)$ & Sand (\%) & Kategori & Kandungan BO $(\%)$ & Kategori \\
\hline A & 93,82 & 1,73 & 4,45 & Liat & 21,35 & Tinggi \\
B & 87,08 & 1,63 & 11,29 & Liat & 22,71 & Tinggi \\
C & 88,68 & 1,45 & 9,87 & Liat & 22,92 & Tinggi \\
\hline
\end{tabular}

Sumber : Laboratorium Manajemen Sumberdaya Perairan FPIK dan Laboratorium Ilmu Tanaman Makanan Ternak FPP, Universitas Diponegoro

Berdasarkan pada Tabel 4 dapat dilihat bahwa analisis tekstur tanah dan kandungan bahan organik, diperoleh jenis substrat dasar pada ketiga stasiun merupakan kategori tanah liat, sedangkan kandungan bahan organik yang diperoleh dalam ketegori tinggi. Menurut Irmawan (2010) pada sedimen yang halus presentase bahan organik lebih tinggi daripada sedimen yang kasar, hal ini juga dipengaruhi oleh kondisi lingkungan, dimana lingkungan yang tenang memungkinkan pengendapan lumpur yang diikuti akumulasi bahan organik ke dasar perairan, sedangkan pada sedimen yang kasar, kandungan bahan organiknya rendah karena partikel yang lebih halus tidak mengendap. Tingginya bahan organik yang masuk ke perairan berasal dari peningkatan aktivitas di daratan seperti pemupukan di sawah dan tambak, budidaya baik tumbuhan maupun ikan di tambak, industri dan aktivitas rumah tangga yang masuk ke dalam badan air dan mengendap di dasar perairan (Faizal et al., 2011).

\section{Parameter Kualitas Air}

Parameter kualitas air yang diukur meliputi kedalaman, kecerahan, kecepatan arus, suhu, oksigen terlarut, salinitas, dan pH. Hasil pengukuran parameter kualitas air pada ketiga stasiun tersaji pada tabel 5. Tabel 5. Nilai Kisaran Rata-rata Parameter Kulitas Air di Sungai Wedung Kabupaten Demak

\begin{tabular}{|c|c|c|c|c|c|c|}
\hline \multirow{2}{*}{ Parameter } & \multicolumn{6}{|c|}{ Stasiun } \\
\hline & \multicolumn{2}{|r|}{ A } & \multicolumn{2}{|c|}{$\mathrm{B}$} & \multicolumn{2}{|r|}{$\mathrm{C}$} \\
\hline Kedalaman (m) & 1,68 & $-1,98$ & 1,37 & $-1,81$ & 1,24 & $-1,73$ \\
\hline Kecerahan (m) & 0,39 & $-0,51$ & 0,43 & $-0,46$ & 0,40 & $-0,47$ \\
\hline Kecepatan Arus (m/s) & 0,25 & $-0,37$ & 0,31 & $-1,11$ & 0,22 & $-0,75$ \\
\hline Suhu Permukaan $\left({ }^{0} \mathrm{C}\right)$ & 29,97 & $-31,93$ & 31,17 & $-31,93$ & 31,37 & $-31,90$ \\
\hline Suhu Dasar $\left({ }^{0} \mathrm{C}\right)$ & 29,90 & $-31,50$ & 30,57 & $-31,47$ & 30,90 & $-31,40$ \\
\hline DO Permukaan (mg/l) & 1,63 & $-3,47$ & 1,50 & $-2,63$ & 1,83 & $-2,63$ \\
\hline DO Dasar $(\mathrm{mg} / \mathrm{l})$ & 0,63 & $-1,50$ & 0,93 & $-2,07$ & 1,13 & $-1,43$ \\
\hline Salinitas $(\% 00)$ & \multicolumn{2}{|c|}{0} & \multicolumn{2}{|c|}{0} & 0,3 & \\
\hline pH Air & \multicolumn{2}{|r|}{8} & \multicolumn{2}{|r|}{8} & \multicolumn{2}{|r|}{8} \\
\hline
\end{tabular}

Sumber : Data Primer Penelitian di Perairan Sungai Wedung Kabupaten Demak Tahun 2013

Berdasarkan pengukuran kedalaman perairan pada masing-masing stasiun nilai kisaran rata-rata kedalaman berturut-turut yaitu, stasiun A berkisar antara 1,68 m - 1,98 m, pada stasiun B berkisar 1,37 m 1,81 m, sedangkan pada stasiun $\mathrm{C}$ berkisar antara 1,24 $\mathrm{m}-1,73 \mathrm{~m}$. Kedalaman suatu perairan, berhubungan terhadap kelimpahan makrozoobenthos, dimana peningkatan kedalaman air diikuti dengan penurunan kelimpahan makrozoobenthos, sebaliknya kelimpahan makrozoobenthos lebih tinggi di perairan yang dangkal (Sulistiyarto, 2008). Kecerahan di stasiun A diperolehkisaran rata-rata antara $25 \mathrm{~cm}-37 \mathrm{~cm}$, stasiun B berkisar $43 \mathrm{~cm}-46 \mathrm{~cm}$, dan di stasiun $\mathrm{C}$ antara $40 \mathrm{~cm}-47 \mathrm{~cm}$. Kecerahan perairan tergantung pada warna dan kekeruhan, jika kekeruhan tinggi atau kecerahan rendah dapat mengakibatkan terganggunya sistem osmoregulasi, misalnya pernapasan dan daya lihat organisme akuatik, serta dapat menghambat penetrasi cahaya ke dalam air (Effendi, 2003). Kecepatan arus pada lokasi penelitian berkisar antara 0,11 - 1,00 $\mathrm{m} /$ detik. Hal ini menunjukan bahwa kecepatan arus di lokasi penelitian relatif kencang. Sebagaimana menurut Effendi (2003) bahwa perairan lotik dicirikan oleh arus yang searah dan relatif kencang, dengan kecepatan arus berkisar antara $0,1-1,0 \mathrm{~m} /$ detik, serta sangat dipengaruhi oleh waktu, iklim, dan pola drainase. Berdasarkan penelitian, pengukuran suhu perairan didapatkan kisaran suhu di bagian permukaan dan bagian dasar perairan pada masing-masing stasiun relatif sama antara $29,8^{\circ} \mathrm{C}-32^{\circ} \mathrm{C}$ sedangkan pada bagian dasar berkisar antara $29,8^{\circ} \mathrm{C}-31,9^{\circ} \mathrm{C}$. Perbedaan suhu permukaan dan suhu dasar disebabkan oleh cahaya matahari yang masuk ke perairan akan mengalami penyerapan dan perubahan menjadi panas, proses 
penyerapan cahaya ini berlangsung secara lebih intensif pada lapisan atas sehingga lapisan atas perairan memiliki suhu yang lebih tinggi (lebih hangat) dengan suhu relatif $28^{\circ} \mathrm{C}-32^{\circ} \mathrm{C}$ (Effendi, 2003).

Kelarutan oksigen dalam perairan merupakan salah satu penentu karakteristik kualitas air yang terpenting dalam kehidupan akuatis. Berdasarkan penelitian, kisaran oksigen terlarut (DO) dari ketiga stasiun antara $0,63 \mathrm{mg} / \mathrm{l}-3,47 \mathrm{mg} / \mathrm{l}$ termasuk rendah. Berkurangnya oksigen terlarut dapat mengakibatkan masalah yang cukup serius bagi kehidupan hewan makrozoobenthos, berkurangnya oksigen di suatu perairan biasanya dikaitkan dengan tingginya bahan organik yang masuk ke dalam perairan (Zahidin, 2008). Menurut Sinaga (2007), banyaknya bahan organik di dalam perairan menyebabkan menurunnya kadar oksigen terlarut di dalam perairan dan jika keadaan ini berlangsung lama menyebabkan perairan menjadi anaerob, sehingga organisme aerob akan mati. $\mathrm{pH}$ perairan di semua stasiun berdasarkan pengukuran, nilai $\mathrm{pH}$ sebesar 8. Pada $\mathrm{pH}$ yang optimum, maka organisme yang hidup di dalamnya akan bertahan, sebaliknya jika $\mathrm{pH}$ perairan terlalu tinggi atau terlalu rendah akan mempengaruhi ketahanan hidup organisme di dalamnya (Odum,1993). Menurut Effendi (2003) bahwa sebagian besar biota akuatik akan sensitif jika terdapat perubahan pH, sedangkan kisaran $\mathrm{pH}$ yang disukai sekitar $7-8,5$.

\section{Hubungan Bahan Organik dengan Kelimpahan Makrozoobenthos}

Hubungan antara kandungan bahan organik dengan kelimpahan makrozoobenthos dianalisis menggunakan analisis regresi linier. Pada hasil analisis, diperoleh nilai korelasi (r) sebesar 0,839 lebih besar dari 0,5 menunjukan bahwa korelasi antara kedua variabel kuat, sedangkan koefisien determinasi $\left(\mathrm{R}^{2}\right)$ sebesar 0,704 artinya $70,4 \%$ bahan organik mempengaruhi kelimpahan makrozoobenthos, selebihnya dipengaruhi oleh faktor lain. Untuk lebih jelasnya dapat dilihat pada grafik hubungan antara bahan organik dengan kelimpahan makrozoobenthos sebagai berikut:

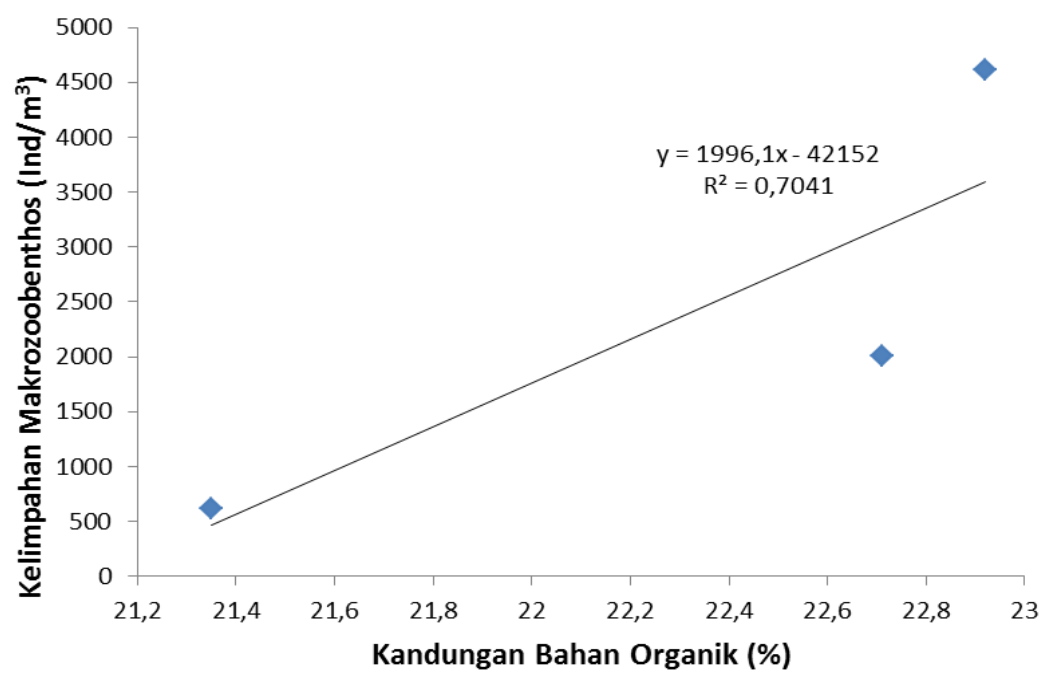

Gambar 3. Grafik Hubungan Kandungan Bahan Organik dengan Kelimpahan Makrozoobenthos

Berdasarkan grafik hubungan kandungan bahan organik dengan kelimpahan makrozoobenthos di atas terlihat bahwa garis linier membentuk persamaan $Y=1996,1 X-42152$. Persamaan linier tersebut menunjukkan bahwa adanya hubungan yang bersifat positif antara bahan organik dengan kelimpahan makrozoobenthos, artinya jika kandungan bahan organik semakin besar maka kelimpahan makrozoobenthos cenderung semakin besar. Menurut Nurracmi dan Marwan (2012), menyatakan bahwa hewan benthos erat kaitannya dengan tersedianya bahan organik yang terkandung dalam substrat, karena bahan organik merupakan sumber nutrien bagi biota yang pada umumnya terdapat pada substrat dasar. Namun jika keberadaan bahan organik melebihi ambang batas sewajarnya maka kedudukan bahan organik tersebut dianggap sebagai bahan pencemar.

\section{Kesimpulan}

Kesimpulan yang didapat dari penelitian ini antara lain :

1. Komposisi makrozoobenthos yang ditemukan selama penelitian terdiri dari 8 genera dari 3 kelas yaitu, kelas Polychaeta terdiri dari Nereis, Nepthys, dan Sphaerodoropsis, kelas Gastropoda terdiri dari Melanoides, Lymnaea, dan Physa, sedangkan dari kelas Bivalve terdiri dari Dreissena dan Sphaerium. Kelimpahan makrozoobenthos di stasiun A sebesar 622 individu $/ \mathrm{m}^{3}$, di stasiun B sebesar 2.007 individu $/ \mathrm{m}^{3}$ dan di stasiun $\mathrm{C}$ sebesar 4.615 individu $/ \mathrm{m}^{3}$.

2. Adanya hubungan antara kandungan bahan organik dengan kelimpahan makrozoobenthos yaitu semakin tinggi kandungan bahan organik maka semakin tinggi kelimpahan makrozoobenthos. 
3. Kondisi perairan di Sungai Wedung Kabupaten Demak termasuk dalam kategori sudah tercemar. Pada stasiun B dan stasiun C nilai indeks keanekaragaman masing-masing sebesar 0,340 dan 0,295 termasuk tercemar karena letaknya berada di daerah pemukiman dan pertambakkan yang membuang limbah domestik dan sisa buangan kegiatan budidaya pada badan sungai, sehingga kualitas perairan Sungai Wedung menurun.

\section{Ucapan Terima Kasih}

Ucapan terima kasih ditujukan kepada Ibu Ir. Siti Rudiyanti, MSi dan Bapak Dr. Ir. Max Rudolf Muskananfola, MSc atas bimbingannya dalam penyusunan jurnal penelitian ini.

\section{Daftar Pustaka}

Buchanan J. B., 1971. Sediments, in: Methods for the study of marine benthos, edited by N.A. Holme and A. Mclntyre, IBP Handbook no 16, Oxford University Press, Oxford, 35-3

Effendi, H. 2003. Telaah Kualitas Air Bagi Pengelolaan Sumberdaya dan Lingkungan Perairan. Kanisius. Yogyakarta.

Faizal, A., J. Jompa. dan C. Rani. 2011. Dinamika Spasio-Temporal Tingkat Kesuburan Perairan di Kepulauan Spermonde Sulawesi Selatan. Jurusan Ilmu Kelautan, FIKP Universitas Hasanuddin, Sulawesi Selatan.

Fitriana, Y. R. 2005. Keanekaragaman dan Kemelimpahan Makrozoobenthos di Hutan Mangrove Hasil Rehabilitasi Taman Hutan Raya Ngurah Rai Bali. Jurusan Manajemen Hutan, Fakultas Pertanian, Universitas Lampung, Bandar Lampung.

Irmawan, R. N. 2010. Struktur Komunitas Makrozoobenthos di Estuaria Kuala Sugihan Provinsi Sumatra Selatan. Program Studi Kelautan FMIPA, Universitas Sriwijaya, Sumatra Selatan.

Ismiyati, Hari Budieni dan Kami Hari Basuki. 2004. Buku Ajar Statistika dan Probabilitas. Jurusan Sipil, Fakultas Teknik, Universitas Diponegoro, Semarang, $184 \mathrm{hlm}$.

Nazir, M. 1999. Metode Penelitian. Ghalia Indonesia. Jakarta.

Nurrachmi, I. dan Marwan. 2012. Kandungan Bahan Organik Sedimen dan Kelimpahan Makrozoobenthos sebagai Indikator Pencemaran Perairan Pantai Tanjung Uban Kepulauan Riau. LIPI Universitas Riau. Pekanbaru.

Odum, E. P. 1971. Fundamental of ecology third edition. W. B. Saundera Company. Philidelphia. 1993. Dasar-dasar Ekologi. Edisi Ketiga. Diterjemahkan oleh Eidman dan Bangen. P.T. Gramedia. Jakarta.

Rosenberg, D. M. and V. H. Resh. 1993. Freshwater Biomonitoring and Benthic Makroinvertebrata. London. Champman and Hall.

Setiawan, D. 2009. Studi Komunitas Makrozoobenthos di Perairan Hilir Sungai Lematang Sekitar Daerah Pasar Bawah Kabupaten Lahat. Jurusan Biologi FMIPA, Universitas Sriwijaya, Sumatra Selatan.

2010. Studi Komunitas Makrozoobenthos di Perairan Sungai Musi Sekitar Kawasan Industri Bagian Hilir Kota Palembang. Jurusan Biologi FMIPA, Universitas Sriwijaya, Sumatra Selatan.

Setyowati, Wahyulis., Vita Naurina, Desintan Wulan, Arista Wahyu, Agustin Merdekawati dan Karni. 2010. Analisis Data. Pendidikan Pra Sekolah dan Sekolah Dasar, Fakultas Ilmu Pendidikan Universitas Negeri Yogyakarta.

Sinaga, T. 2009. Keanekaragaman Makrozoobenthos sebagai Indikator Kualitas Perairan Danau Toba Balige Kabupaten Toba Samosir. [Tesis]. Universits Sumatra Utara. Medan.

Sulistiyarto, B. 2008. Keterkaitan Antara Kelimpahan Makrozoobenthos dengan Parameter Fisika Kimia Air di Danau Hanjalantung Palangka Raya Kalimantan Tengah. Fakultas Perikanan, Universitas Kristen Palangka Raya, Kalimantan Tengah

Zahidin, M. 2008. Kajian Kualitas Air Di Muara Sungai Pekalongan Ditinjau dari Indeks Keanekaragaman Makrobenthos dan Indeks Saprobitas Plankton. [Tesis]. Program Pascasarjana, Universitas Diponegoro. Semarang.

Zulkifli, H. 2009. Struktur dan Fungsi Komunitas Makrozoobenthos di Perairan Sungai Musi Kota Palembang: Telaah Indikator Pencemaran Air. Jurusan Biologi FMIPA, Universitas Sriwijaya, Sumatra Selatan. 